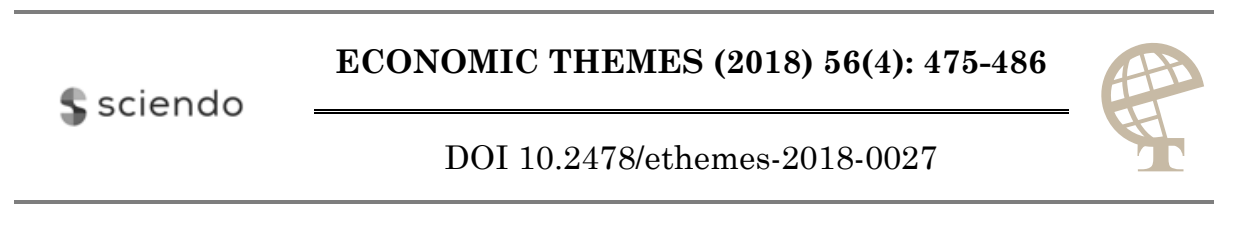

\title{
EXAMINATION OF SATISFACTION LEVEL OF BANK SERVICE CUSTOMERS USING SERVQUAL MODEL
}

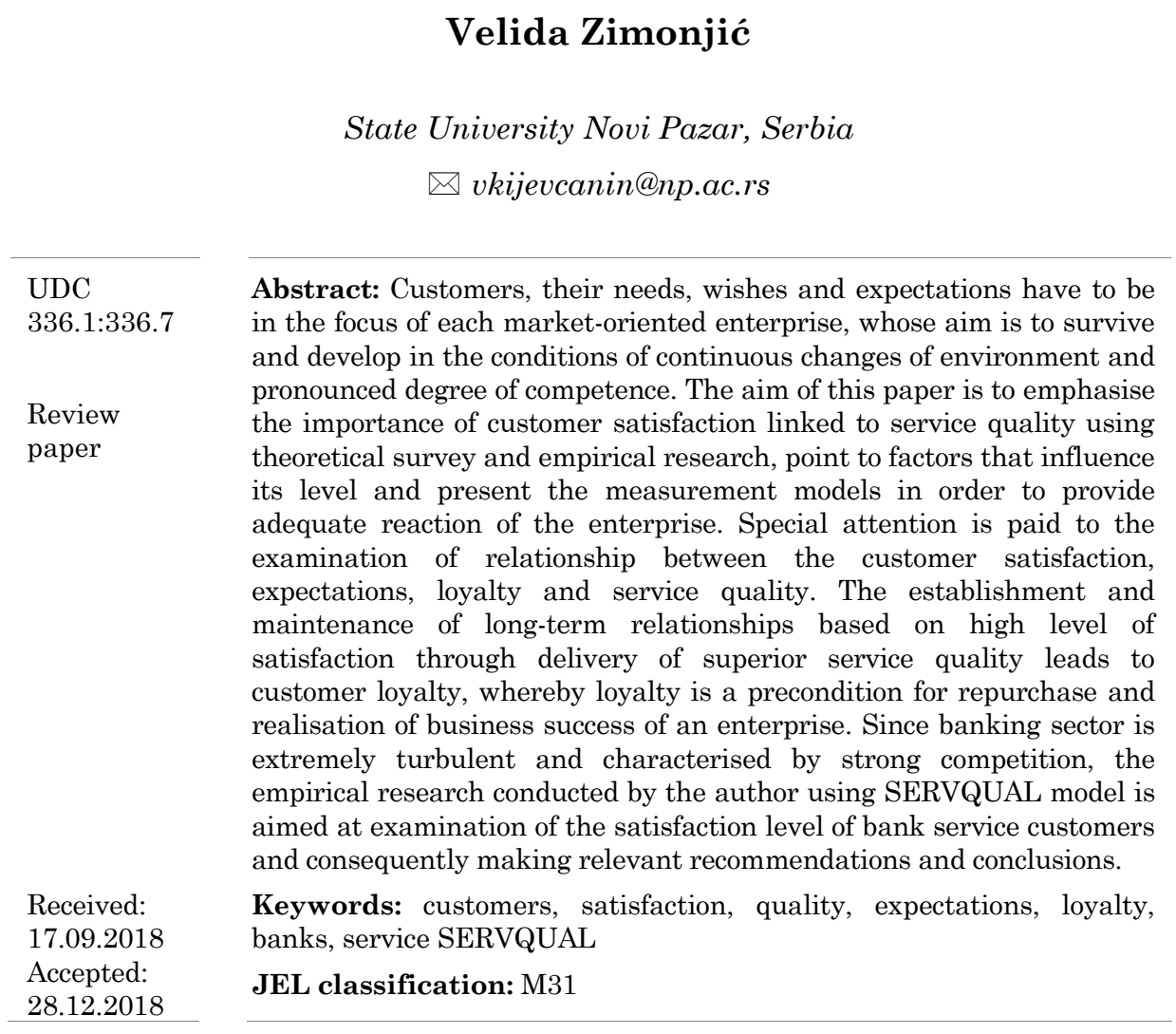

\section{Introduction}

Understanding the needs, wishes and expectations of customers is the base for providing customers with satisfactory service quality. Customer satisfaction with the quality of given service is increasingly significant since the struggle for customers in contemporary business conditions has become necessity. In the circumstances of strong competition, the attraction of new customers is very difficult and needs great investment, hence the enterprises especially emphasise the 
customer retention by raising the level of their satisfaction with the quality and value of provided services, in order to establish and maintain long-term relationships. The banks that want to survive despite strong market competition which comes from other non-banking institutions, should know their target market well, recognise needs and wishes of their clients, thus creating appropriate service by combining market mix instruments to gain a high level of client satisfaction and satisfactory profit. (Angur, et al., 1999; Vukosavljević, et al., 2011; Ljubojević, 1997; 2000; Radojević \& Marjanović, 2011, Senić, 1999)

Satisfaction is fundamental for client retention and their loyalty, and accordingly, gaining highest possible level of customer satisfaction is one of primary aims of market-oriented enterprises. (Fornell, et al., 1996; Oliver, 1997, Chiou \& Droge, 2006) Meanwhile, customers have become more conscious, demanding, informed and have greater possibility of selection in deciding about purchase, which requires great effort of an enterprise to retain them. There are no other guarantees for success and survival of an enterprise, except superior value of the service, which will be recognised by customers as perfect service quality, and which they are ready to pay. Thus, a high satisfaction level is gained, customer loyalty is acquired and the precondition for strengthening the relationships with current customers is realised, while satisfied customers transfer their positive experience to others by mouth-to-mouth communication, thus promoting the enterprise and attracting new customers. The enterprises that do business on finance market tend to create long-term relationships with their clients, based on confidence, value and quality of the provided services.

The subject of the conducted empirical research was the examination of the level of satisfaction of bank service users with the quality of services provided by banks on the territory of Serbia. On the basis of the obtained results, the aim of the research was to identify the satisfaction of examinees with the quality of services provided by banks, as well as aspects of quality that satisfied bank service users and those that did not, so that certain recommendations related to increased satisfaction could be made. The examinees were offered to choose one of five levels of satisfaction with the bank services such as: not satisfied at all, not satisfied, partly satisfied, satisfied and very satisfied. The application of the SERVQUAL model served to examine the satisfaction of bank service users by questions that were relevant for assessment of quality of the provided services. The examinees ranked the quality of following services from 1-5: modernity of equipment, tidiness of staff, tidiness of area, attractiveness of resources, attractiveness of ambience, information for clients, keeping promises, kindness of staff, respect the agreed time, sense of safety, data accuracy, ability of the staff to provide prompt service, readiness of the staff to help, understanding for clients, suitability of bank working hours, adequacy of service for the first and each and subsequent time, staff knowledge and care. 


\section{Significance and measuring satisfaction of bank service users}

Satisfaction is a result of experience, i.e. pleasure with the obtained service, but it can also be the result of the evaluation process and perception. Common components of numerous definitions of customer satisfaction defined by Giese \& Cote (2000) after a search through literature are:

- Satisfaction is a reaction (emotional or cognitive);

- Satisfaction is a reaction to expectation, product, service or experience;

- Satisfaction appears at certain time after consumption, selection, on the basis of experience.

Customer satisfaction did not draw the attention it deserved, but in time it gained significance, and the enterprises have now become aware that it is a powerful weapon in merciless competitive struggle for client retention and attraction. Satisfaction contributes to profit increase for the enterprise through repeated purchases, which will happen in case customers are satisfied with the quality of the provided service.

Activities of an enterprise, primarily in marketing, should be directed towards the stimulation of repeated purchases, by maintaining the relationship with customers based on satisfaction with the service quality and value, obtained for the invested money.

The effects gained from customer satisfaction are numerous, and some of the most significant, listed in the literature (Marinković, 2009; Caruana, 2002; Tam, 2004; Churchil \& Surprenant, 1982; Mohsin, et al., 2012; Lovreta, et al., 2010) are the following:

- Readiness of customers to buy more, if they feel good during the purchase process;

- Dissemination of positive experience related to services;

- Repeated purchase and

- Loyalty to the enterprise, even after the change of conditions or increased price of services.

Customer satisfaction and its effects on business success of the enterprise should be followed by establishing efficient system of measurement, which will not be based on periodical measuring only, but will include continual measuring, harmonised with characteristics of the enterprise. The process of determining satisfaction level should primarily rely on customers. It is necessary to publicly define the aim of research, methods of data collection, samples and leaders of research. After the conducted research, data presentation follows as a very significant element, since further steps related to improvement of satisfaction depend on the presentation methodology. 
Most often used techniques for measurement of satisfaction are the system of reclamation, inquiry of pleasure, anonymous purchase and lost customer analysis. The index of customer satisfaction is one of the most frequently used parameters and is used in order to measure the influence of various variables on the customer satisfaction level, while the methodology of measurement can be applied on individuals, market segment, a sector or economy as a whole. American Customer Satisfaction Index is based on the cognition that satisfaction cannot be measured directly, since it involves subjective attitude of a customer about quality, thus the methodology is built on expectations based on experience. Quality, value and expectations are measured by using this Index. (Evans \& Lindstay, 2016; Fahnrich \& Spath, 2006; Stanković \& Đukić, 2013; Đukić, 2006; Kotler, et al., 2007)

Measuring customer satisfaction is regulated by quality standard ISO 90012000 , which requires establishment of appropriate system for measuring the level of customer satisfaction, since the obtained results make it possible to react in order to improve business performance of the enterprise. To act in accordance with this standard, enterprises have to be oriented towards customers, especially to provide resources for increase of satisfaction level; satisfaction should be the parameter of business performance, and the analysis of the obtained data should be carried out. (Bugdol \& Jedyinak, 2014; Marinković, 2010)

Standardisation in the banking sector is intensified with the development of contemporary technology, therefore ISO standards for banking are defined by Technical Committee ISO-TC 68 and subcommittees, responsible for operations and procedures (SC2), securities (SC4), exchange information in banking (SC5), financial transaction cards (SC6). This organisation includes over 90 countries, and the advantages of introduction of ISO standards are numerous. In accordance with the international standards ISO 3000, banks are obliged to offer the products and services that are harmonized with customer demands, standards and legal regulations, then to have competitive prices and provide profit. (Talib, et. al., 2012; Veljković, 2008)

\section{Relationship between customer satisfaction, expectation, loyalty and service quality}

Gaining satisfaction is not at all an easy task because it involves a complex process and function of customer perception and expectation: satisfaction = perception expectation, whereby expectations correspond to the probability of event while perception is its assessment. Before they decide to purchase something, customers estimate the value of offers at their disposal. Purchase satisfaction depends on the extent to which the product or service meets the customer expectations. If the expectations are met, the customer is satisfied, if not, the customer is dissatisfied; if the expectations exceed, and the customer is very satisfied; this should be the objective of market-oriented enterprises. 
Considering the significance of customer expectations, the question of their origins arises. Expectations are formed on the basis of the previous experience, attitudes of friends, acquaintances, service promises etc. The level of service expectations should be carefully established by the enterprises, because in case the expectations are too low, they may keep the old but will not attract new customers, while too high unfulfilled expectations may lead to customer disappointment. Quality and satisfaction are conditioned by expectations and experience, and the quality and customer satisfaction determine future decisions of customers on purchase, i.e. the possibility of establishing and maintenance the relationship with customers. (Iacobucci, et al., 1995, pp. 280)

Quality of service is more difficult to define in comparison to quality product. Due to specificity of services, the mere procedure of measurement and identification of quality determinants from the customer viewpoint is getting more complex. Quality from the customer viewpoint includes not only the evaluation of benefits obtained from service to service and harmonization of service with expectations, but also assessment of the whole servicing procedure. Quality of service is a multidimensional structure. There is consensus in the literature that three basic elements of quality of service are quality of results, quality of interaction and quality of servicing environment. (Đukić \& Kijevčanin, 2013; Pollack, 2008)

Customer satisfaction with the quality of provided service is conditioned by fulfilment of expectations. Service satisfaction, i.e. dissatisfaction is a result of comparison between the obtained and expected quality. Although the relation and blend of concepts of quality and satisfaction are recognised in the literature, it should be pointed out that aspects which emphasise quality are rather specific; satisfaction involves even wider range of aspects, including the aspects of quality, demand and customer experience, while quality does not require them. (Bebko, 2000; Marinković, 2010; Caruana, et. al., 2000; Akbar \& Parvez, 2009) Sureshchandar et al., (2003) identified strong connection between quality of service and customer satisfaction, while at the same time they emphasised variety of concepts from the customer's viewpoint.

The degree of satisfaction is in positive correlation with long-term performances, i.e. greater level of customer satisfaction leads to increased loyalty, which has further impact on repurchase growth. However, in order to achieve loyalty, customer delight with service is increasingly required; only exceptionally satisfied customers will convey their positive experience to others, thus promoting the enterprise and the offered services. Higher degree of loyalty leads to increased purchase, while positive propaganda leads to rise of profit over a long time. It should be emphasised that the relation between satisfaction and loyalty, which is mainly positive, need not necessarily, be such, since it is influenced by numerous parameters, whether related to enterprise activities or unexpected customer behaviour. (Grubor, 2011; Marinković, 2010) 
From customer viewpoint the core of satisfaction lies in contentment, or even in surpassing expectations, while the highest degree of satisfaction is achieved when the consumer is delighted with the quality of provided service (Ljubojević, 2002; Olsen, 2002) Quality in banking implies surpassing customer expectations, which can be realised only by using modern technology aimed at improving the complete service process, dedication to continual improvements and marketing of relationships with clients. The needs for services based on technology, new and facilitated services and electronic services are very significant aspects that contribute to improvement of bank service quality (Muhammad, et. al., 2011)

\section{Research results}

For the needs of research, a structured questionnaire ${ }^{1}$ was used; it included questions related to degree of client satisfaction and the SERVQUAL model, which was the most widely applied in developing countries for measuring bank service quality, although numerous research showed the advantages of the SERVPERF model for this purpose. (Ljubojević, 2000; Angur et. al., 1999; Culiberg, et al., 2010)

In accordance with the initial theoretical analyses, the outdoor research was designed to be conducted by using questionnaires with the items significant for identification of satisfaction degree; 800 questionnaires were distributed in 5 cities in percentages of population recorded by last census as following: Belgrade (530 examinees), Novi Sad (104), Niš (80), Kragujevac (56) and Novi Pazar (32) by the method of random selection of passers-by. ${ }^{2}$ The research was conducted in 2014/2015. Considering gender, the number of examinees was nearly equal, 396 males and 404 females. Out of total number of the examinees, the greatest number were aged 38-47 years (203) and 28-37 years (198), while the smallest number were those aged over 67 years (40) and 58-67 years (77). The greatest number of examinees were permanently employed (253), part time employees (153), and the retired (70), while the smallest number were students (50). Out of total number of examinees, (800), 618 stated that they had monthly income of more than 100,000 dinars per household. When the sample is observed by professions of examinees, the employees in public sector prevailed (161 examinees), followed by education (120), catering 119), trade (114) and industry (83), while the fewest were students of doctoral studies (69) and undergraduate students (49).

The results of conducted research served to portray more clearly the degree of customer satisfaction of bank service users on the territory of Serbia and to make certain decisions and significant recommendations. The results of research on the degree of customer satisfaction are given in Table 1.

1 The conducted research is a part of more extensive investigation of client attitudes and bank management in Serbia

${ }^{2}$ The data presented in this paper are a result of more extensive research conducted by the author 
Table 1. The degree of satisfaction of bank service users

\begin{tabular}{|c|c|c|c|c|c|}
\hline & Degree of satisfaction & Frequency & Percentage & $\begin{array}{c}\text { Valid } \\
\text { percentage }\end{array}$ & $\begin{array}{l}\text { Cumulative } \\
\text { percentage }\end{array}$ \\
\hline \multirow{6}{*}{ Valid } & Not at all satisfied & 9 & 1.1 & 1.1 & 1.1 \\
\hline & Not satisfied & 119 & 14.8 & 14.9 & 16.0 \\
\hline & Partly satisfied & 316 & 39.4 & 39.5 & 55.6 \\
\hline & Satisfied & 313 & 39.0 & 39.2 & 94.7 \\
\hline & Very satisfied & 42 & 5.2 & 5.3 & 100.0 \\
\hline & Total & 799 & 99.6 & 100.0 & \\
\hline \multicolumn{2}{|r|}{ Missing } & 3 & .4 & & \\
\hline \multicolumn{2}{|l|}{ Total } & 802 & 100.0 & & \\
\hline
\end{tabular}

Source: The presented data were obtained by the author's research

Client satisfaction was also examined by application of the SERVQUAL model which included the analysis of client attitudes about certain elements of service quality; the results are shown In Table 2. The average grade of client attitudes related to the service quality varies in the range of 4.21-3.10. Client satisfaction, expressed in the value of the average grade of examinees is given in Table 2, from the highest to the lowest.

\section{Discussion of research results}

Based on the data obtained by outdoor research about the degree of satisfaction of examinees, shown in Table 1, it can be concluded that partly satisfied clients (316) are predominant, to be followed by also a great number of satisfied (313), while only 43 are very satisfied. Nine clients are not at all satisfied, while 119 are not satisfied, which should not be neglected. These data show that banks in Serbia are aware of the importance of customer satisfaction, but that here is still enough capacity for the improvement of provided service quality and the degree of satisfaction. Since it has already been emphasized that banks operate on a very competitive market, and that exceeding customer expectations in quality is necessary, the number of 42 very satisfied clients in comparison to 799 interviewed should be a significant indicator that banks have to work continuously on recognition of customer needs, demands, and fulfilment of their expectations, in order to keep them and realise their long-term aims. 
Table 2. SERVQUAL model for bank service users

\begin{tabular}{|l|c|c|c|c|c||}
\hline \multicolumn{1}{|c|}{ User attitudes } & $\begin{array}{c}\text { No. of } \\
\text { examinees }\end{array}$ & Min. & Max & Average & $\begin{array}{c}\text { Standard } \\
\text { deviation }\end{array}$ \\
\hline Modern equipment & 800 & 1.00 & 5.00 & 4.2088 & .78482 \\
\hline Tidy employees & 800 & 1.00 & 5.00 & 4.1450 & .78246 \\
\hline Tidy area & 800 & 1.00 & 5.00 & 4.1412 & .78394 \\
\hline Attractive resources & 800 & 1.00 & 5.00 & 4.0412 & .79865 \\
\hline Attractive ambience & 800 & 1.00 & 5.00 & 4.0363 & .79418 \\
\hline Information for clients & 800 & 1.00 & 5.00 & 3.7462 & .94762 \\
\hline Keeping promises & 800 & 1.00 & 5.00 & 3.4137 & .82061 \\
\hline Kindness of staff & 800 & 1.00 & 5.00 & 3.4075 & .82145 \\
\hline Respect the agreed time & 800 & 1.00 & 5.00 & 3.4000 & .80983 \\
\hline Confidence in the staff & 800 & 1.00 & 5.00 & 3.3950 & .80764 \\
\hline Sense of safety & 800 & 1.00 & 5.00 & 3.3875 & .80973 \\
\hline Data accuracy & 800 & 1.00 & 5.00 & 3.3750 & .81099 \\
\hline $\begin{array}{l}\text { Ability of the staff to } \\
\text { provide prompt service }\end{array}$ & 800 & 1.00 & 5.00 & 3.3738 & .81079 \\
\hline $\begin{array}{l}\text { Readiness of the staff to } \\
\text { help }\end{array}$ & 800 & 1.00 & 5.00 & 3.3113 & .83830 \\
\hline $\begin{array}{l}\text { Understanding for } \\
\text { clients }\end{array}$ & 800 & 1.00 & 5.00 & 3.3100 & .84249 \\
\hline $\begin{array}{l}\text { Suitability of bank } \\
\text { working hours }\end{array}$ & 800 & 1.00 & 5.00 & 3.2800 & .90837 \\
\hline Adequacy of service & 800 & 1.00 & 5.00 & 3.2487 & .86331 \\
\hline Staff knowledge & 800 & 1.00 & 5.00 & 3.2462 & .86980 \\
\hline Care for clients & 800 & 1.00 & 5.00 & 3.0988 & .87031 \\
\hline Valid & 800 & & & & \\
\hline
\end{tabular}

Source: The presented data were obtained by the author's research

Considering the results of examination of customer satisfaction with the aspects of quality by using SERVQUAL model, the highest degree of satisfaction is related to modernity of equipment, as it is shown in Table 2, where the average value of attitudes of 800 examinees is 4.21 ; this means that banks invest in their equipment, which results in satisfaction of a large number of the interviewed clients. Similar situation is in the following aspects of quality: tidiness of staff (4.14), tidiness of ambience (4.14), attractiveness of resources (4.04) and attractiveness of ambience (4.03). Customer satisfaction with the information from the bank is rather great, which is seen in the average value of 3.74. The analysis of the obtained data shows that banks should continuously work on improvement of customer satisfaction in other aspects of quality, because although the degree of satisfaction is not too low 
and ranges from 3.41 for keeping promises and 3.09 for care for clients, strong competition and customer behaviour in contemporary business conditions require customers who are delighted with service, i.e. that the degree of their satisfaction should be as close to maximum as possible for each aspect of the provided service.

\section{Concluding considerations and recommendations}

Considering significance of customer needs, wishes and expectations, and correlation between satisfaction, service quality and customer loyalty, it is clear that in the age of continuous change and modified conditions, market oriented enterprises have great responsibility. They should listen to market and react properly in order to survive and make profit, which can be realised only if customer expectations are recognised and met with services of superb quality. Based on positive experience and a high level of stratification, customer loyalty is achieved, which further leads to establishment of long-term relationship, thus accomplishing primary aim of the enterprise, i.e. business success in the form of repurchase, not single transactions.

The results of the conducted research show that the degree of customer satisfaction with certain aspects of quality is acceptable, but it is necessary to continuously work on improvement of quality in order to gain a higher degree of satisfaction. The analysis of attitudes of bank service customers shows disproportion between their expectations and quality of provided services, which means that banks should make stronger efforts to recognise needs and demands of their clients in order to satisfy them properly and, if possible, surpass their expectations related to quality, since on today's bank market, surpassing client expectations has become necessity for survival and further development, bearing in mind competition which does not sprout from the banks only, but also from other financial institutions that expand their business into this domain as well.

\section{References}

Akbar, M.M., Parvez, N. (2009), „Impact of service quality, trust, and customer satisfaction on customer loyalty“, ABAC Journal, Vol. 29, No.1, pp. 24-38

Angur, M.G., Nataraajan, R., Jahera, J.S. (1999), „Service quality in the banking industry: an assessment in developing economy“, International Journal of Bank Marketing, Vol. 17, No. 3, pp. 116-125

Bebko, C.P. (2000), „Service intangibility and its impact on consumer expectations of service quality“, Journal of Services Marketing, Vol. 14, No. 1, pp. 9-26

Bugdol. M., Jeyinak, P. (2014), Integrated Management Systems, Springer International Publishing, London

Caruana, A., Money, A.H., Berthon, P.R. (2000), „Service quality and satisfaction: the moderating role of value“, European Journal of Marketing, Vol. 34, No. 11/12, pp. 1338-1353 
Caruana, A. (2002), ,Service loyalty: the effects of service quality and the mediating role of customer satisfaction“, European Journal of Marketing, Vol. 36, No. 7/8, pp. 811-828

Chiou, J.S., Droge, C. (2006), ,Service quality, trust, specific asset investment, and expertise: direct and indirect effects in a satisfaction-loyalty framework", Journal of the Academy of Marketing Science, Vol. 34, No. 4, pp. 613-627

Churchill, G.A., Surprenant, C. (1982), „An investigation into the determinants of customer satisfaction", Journal of Marketing Research, Vol. 19, No. 4, pp. 491-504

Culiberg, B., Rojšek, I. (2010), „Identifying service quality dimensions as antecedentes to customer satisfaction in retail banking", Economic and Business Review, Vol. 12, No. 3, pp. 151-166

Đukić, M.S. (2006), „Upravljanje marketingom odnosa sa potrošačima“, doktorska disertacija, Ekonomski fakultet univerziteta u Nišu, Niš

Đukić, M.S., Kijevčanin, V. (2012), „Service quality as determinant of customer satisfaction“, Facta Universitatis, Vol. 9, No. 3, pp. 311-325Evans, J.R., Lindsay, W.M. (2016), Managing for Quality and Performance Excellence, Cengage Learning, 10th edition, Boston, USA

Fahnrich, K.P., Spath, D. (2006), Advances in Services Innovations, Springer Science \& Business Media, Berlin

Fornel, C., Johnson, M.D., Anderson, J.C., Bryant, B.E. (1996), „The American Customer Satisfaction Index: Nature, Purpose, and Findings“, Journal of Marketing, Vol. 60, October, pp. 7-18

Grubor, A. (2011), „Očekivanja, satisfakcija i lojalnost potrošača u marketingu usluga“, Anali ekonomskog fakulteta u Subotici, Vol. 47, Np. 26, pp. 23-32

Giese, J.L., Cote, J.A. (2000), „Defining Consumer Satisfaction“, Academy of Marketing Science Review, Vol. 1, pp. 1-27

Iacobucci, D., Ostorm, A., Grayson, K. (1995), „Distinguishing Service Quality and Customer Satisfaction: The Voice of the Consumer", Journal of Consumer Psychology, Vol. 4, No. 3, pp. 277-303

Kotler, F., Vong, V., Sonders, Dž., Armstrong, G. (2007), Principi marketinga, 4. evropsko izdanje, Mate, Beograd

Lovreta, S., Beman, B., Petković, G., Veljković, S., Crnković, J., Bogetić, Z. (2010), Menadžment odnosa sa kupcima, Data status, Ekonomski fakultet u Beogradu, Beograd

Ljubojević, Č. (1997), „Kvalitet bankarske usluge u funkciji zadržavanja klijenata“, Svet finansija, Novi Sad, No. 169, pp. 48-57

Ljubojević, Č. (2000), „Marketing izazovi savremene banke“, Svet finansija, Novi Sad, Br. 183, pp. 13-20

Ljubojević, C. (2002), Marketing usluga, Stylos, Novi Sad

Marinković, V. (2010), „Efekti lojalnosti potrošača na stvaranje dugoročne profitabilnosti preduzeća“", Poslovna ekonomija, Vol. 4, Br. 2, pp. 633-648

Marinković, V. (2010), „Marketinški koncepti satisfackije i lojalnosti u bankarstvu“, doktorska disertacija, Ekonomski fakultet u Beogradu

Mohsin, Z., Sana, Z., Aasia, A., Ahmed, I.H., Mushtaq, A. (2012), „Service quality, customer satisfaction and loyalty: an empirical analysis of banking sector in Pakistan“, Information management and business review, Vol. 4, No. 3, pp. 159-167

Muhammad, E.M., Basharat, N., Zoune, A. (2011), „Impact of perceived service quality on banking customer loyalty", Interdisciplinary Journal of contemporaty research in business, Vol. 3, No. 8, pp. 637-645 
Oliver, R.L. (1997), Satisfaction: A Behavioral Perspective on the Consumer, McGraw-Hill, New York

Olsen, S.O. (2002), „Comparative evaluation and the relationship between quality, satisfaction and repurchase loyalty"; Journal of the Academy of Marketing Science, Vol. 30, No. 3, pp. 240-249

Pollack, B.L. (2008), „The nature of the service quality and satisfaction relationship: empirical evidence for the existence of satisfier and dissatisfiers", Managing Service Quality, Vol. 18, No. 6, pp. 537-558

Radojević, P., Marjanović, D. (2011), „Kvalitet usluga u bankarstvu: nesaglasnosti, odrednice i istraživačke tehnike za unapređenje kvaliteta“, Bankarstvo, Vol. 40, No. 7-8, pp. 34-59

Senić, R. (1999), „Zadržavanje kupaca (retencioni marketing)“, Ekonomski horizonti, Vol. 1, No. 1-2, pp. 9-29

Stanković, Lj., Đukić, S. (2013), Marketing, drugo izdanje, Ekonomski fakultet u Nišu, Niš

Sureshchandar, G.S., Rajendran, C., Anantharaman, R.N. (2002), „The relationship between service quality and customer satisfaction - a factor specific approach“, Journal of Service Marketing, Vol. 16, No. 4, pp. 363-379

Talib, F., Rahman, Z., Qureshi, M.N. (2012), „Impact of Total Quality Management and Service Quality in the Banking Sector", Journal of Telecommunications System \& Management, OMICS Publich Group, Vol. 1. No. 2, pp. 1-5

Tam, J.L.M. (2004), „Customer satisfaction, service quality and perceived value: an integrative model“", Journal of Marketing Management, Vol. 20, No. 7/8, pp. 897-917

Veljković, J. (2008), „Finsnsijska industrija prema ISO standardima“, master rad, Univerzitet Singidunum

Vukosavljević, D., Radulović, M., Vukosavljević, D. (2011), „Faktori koji utiču na neophodnost marketinške usmerenosti banaka“, Ekonomija: teorija i praksa, Vol. 4, No. 4, pp. 27-39

\section{ISPITIVANJE NIVOA SATISFAKCIJE KORISNIKA BANKARSKIH USLUGA PRIMENOM SERVQUAL MODELA}

Abstrakt: Potrošači, njihove potrebe, želje i očekivanja moraju biti u fokusu svakog tržišno orijentisanog preduzeća koje ima za cilj da opstane i razvija se u uslovima kontinuiranih promena u okruženju i izrazitog stepena konkurencije. Cilj ovog rada jeste da se kroz teorijski osvrt i empirijsko istraživanje istakne značaj koji ima satisfakcija potrošača kvalitetom pružene usluge, ukaže na faktore koji utiču na njen nivo i da se prikažu načini za njeno merenje u cilju pravovremenog reagovanja od strane preduzeća. Posebna pažnja data je ispitivanju odnosa koji postoji između satisfakcije potrošača, očekivanja, lojalnosti i kvaliteta usluga. Uspostavljanje i negovanje dugoročnih odnosa koji su bazirani na ostvarivanju visokog nivoa satisfakcije kroz isporuku usluge superiorne vrednosti vodi lojalnosti potrošača, a lojalnost predstavlja preduslov ponovnih kupovina i ostvarivanja poslovnog uspeha preduzeća. S obzirom da je bankarski sektor izuzetno turbulentan i da ga karakteriše intenzivna konkurencija, konkretno empirijsko istraživanje koje je sproveo autor usmereno je na ispitivanje nivoa satisfakcije korisnika bankarskih usluga u Srbiji primenom SERVQUAL modela i poslužilo je za donošenje određenih preporuka i zaključaka.

Ključne reči: potrošači, satisfakcija, kvalitet, očekivanja, lojalnost, banke, usluge, SERVQUAL 


\section{Author's biography}

Velida Zimonjić was born in Novi Pazar on 22 July 1981. She began her career as an associate at the State University of Novi Pazar in 2007 and conducted practical course in Management in Higher Education in master specialised study and undergraduate study programmes at the Department of Economy. Since 2008 she has worked as an associate at the Quality Assurance office at the same University. She was promoted to the position of assistant in 2010. She had a number papers published in domestic and foreign collections and journals. 